\title{
Shading as a conditioning factor to forest species planting: a study with Apuleia leiocarpa
}

\author{
Intensidad de sombra como condición para la plantación de especies forestales: \\ estudio con Apuleia leiocarpa
}

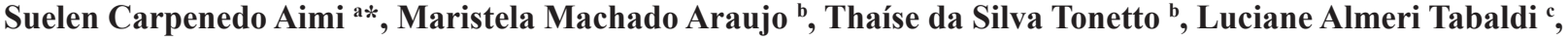

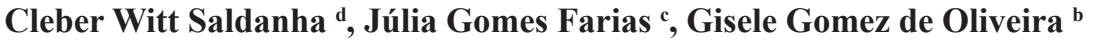 \\ *Autor de correspondência: ${ }^{\text {a }}$ Universidade Federal de Santa Maria, Departamento de Ciências Florestais, \\ Av. Roraima, 1000, CEP 97105-900, Santa Maria, Brasil, tel.: 55-3220-8276, suaimi@gmail.com \\ ${ }^{\mathrm{b}}$ Universidade Federal de Santa Maria, Departamento de Ciências Florestais, Santa Maria, Brasil. \\ c Universidade Federal de Santa Maria, Departamento de Biologia, Santa Maria, Brasil. \\ ${ }^{\text {d}}$ Fundação Estadual de Pesquisa Agropecuária, FEPAGRO, Santa Maria, Brasil.
}

\section{SUMMARY}

This study aimed at identifying the most appropriate level of shading for initial growth of Apuleia leiocarpa seedlings, through their survival, morphological and physiological/biochemical parameters. The following treatments were evaluated: 0 (full sun), 18, 50 and $70 \%$ of shading. Survival was assessed at 30 and 360 days after planting and morphological parameters such as height $(\mathrm{H})$, stem diameter (SD) and H/SD ratio were measured bimonthly for a year. Physiological parameters as contents of chlorophyll $a$, chlorophyll $b$, chlorophyll $a / b$ ratio, carotenoids, lipid peroxidation, acid phosphatase enzyme activity, initial fluorescence, maximum fluorescence, maximum quantum yield of photosystem II and electron transport rate were estimated at 180 and 360 days after planting. At 30 days after planting (d.a.p) there was no mortality of Apuleia leiocarpa seedlings influence of different levels of shading. In the assessments performed at 180 and 360 d.a.p., there was no significant difference among levels of shading for H and SD. However, high mortality rates were observed at 360 d.a.p., especially in full sun. Morphological and physiological parameters of Apuleia leiocarpa plants showed this species requires shading (18 and $50 \%$ ) in their early stages of growth.

Key words: Fabaceae, morphological and physiological parameters, native species.

\section{RESUMEN}

El objetivo de este estudio fue identificar la intensidad de sombra más adecuada para el crecimiento inicial de plantas de Apuleia leiocarpa, por medio de la supervivencia y parámetros morfológicos y fisiológicos/bioquímicos. Los tratamientos fueron: 0 (pleno sol); 18, 50 y $70 \%$ de sombra. La supervivencia se evaluó a los 30 y 360 días después del trasplante y los parámetros morfológicos altura $(\mathrm{H})$, diámetro del cuello (DC) y la relación H/DC, bimensualmente durante un año. Los parámetros fisiológicos contenido de clorofila $a$, clorofila $b$, relación clorofila $a / b$, carotenoides, peroxidación lipídica, actividad de la enzima fosfatasa ácida, fluorescencia inicial, fluorescencia máxima, rendimiento cuántico máximo del fotosistema II y la tasa de transporte de electrones fueron estimados a los 180 y 360 días después del trasplante. A los 30 días después de la siembra (d.a.p) no hubo mortalidad de plántulas de Apuleia leiocarpa ni influencia de diferentes niveles de sombreado En las evaluaciones realizadas a 180 y 360 d.a.p. No hubo diferencia significativa entre los niveles de sombreado para H y SD. Los parámetros morfológicos y fisiológicos de las plantas de Apuleia leiocarpa evidencian que la especie necesita sombra (18 y $50 \%$ ) en su etapa inicial de crecimiento.

Palabras clave: Fabaceae, parámetros morfológicas y fisiológicas, especie nativa.

\section{INTRODUCTION}

Anthropic activities have been causing significant changes in the structure and functioning of ecosystems, resulting in new conditions that lead to alterations of the original environments, consequently, contributing to decrease and loss of species diversity and habitat extinction (Bogaert et al. 2011).
According to a study of endangered native flora of Rio Grande do Sul State (Brazil) (SEMA 2014), several tree species with economic value were identified, including Apuleia leiocarpa J.F. Macbr (grápia), which is among the critically endangered species. Apuleia leiocarpa was described as having commercial value due to high wood qualities, such as easy workability, high natural resistance and multiple uses. Seedlings of Apuleia leiocarpa do 
not present significant regeneration in forests understory being replaced by others with superior tolerance to shade. Furthermore, this species has commercial biotechnology potential due to its antimicrobial effect for combating phytopathogenic bacterium of Xanthomonas campestris (Carvalho et al. 2015). Carvalho (2003) describes that species as having semi-heliophile behavior while Backes and Irgang (2009) classify it as an aggressive pioneer in fallow vegetation, with wide distribution in Brazil and other Latin American countries.

Apuleia leiocarpa has a wide geographic distribution that includes from the state of Pará to Rio Grande do Sul, Brazil, as well as Argentina, Bolivia, Paraguay, Peru and Uruguay (Carvalho 2003). Furthermore, this species is associated with environmental variation of the regions might be a determining factor in the classification of behavior when it comes to light demand. In this context, species with such importance in ecological and timber production should be studied regarding the effects of growth environment, thus enabling its establishment in pure and/or enrichment plantations, with low risk of losses in the field.

The selection of tree species must be established based on the characteristics of the site, planting purpose and, crucially, their physiological, ecological and silviculture requirements (Lamprecht 1990). Lamprecht (1990) also mentions that the main obstacle in native forest refers to insufficient knowledge about tropical tree species. Regarding that, Kageyama and Castro (1989) analyzed forest planting of native species, aiming at systematizing some criteria that would serve as a basis to such research. $\mathrm{Cu}-$ rrently, despite the available and highly relevant work, however, there is a lack of detailing that encourages the use of native tree species of high timber value for outplanting, which could provide species conservation associated with timber use. Although Brancalion et al. (2012) describe the existence of information of Brazilian native species with exception of publications such as Carvalho (2003) and Kageyama and Castro (1989), other experiences are only restricted to queries.

The species requirements regarding intensity, duration and periodicity of light are among the factors that interfere in the production of forest plants (Azevedo et al. 2015). Response of plants to light availability has a central role in determining their distribution and success. Demand for light by native forest species is commonly described based on phytosociological studies (Lima et al. 2010). However, no studies were found evaluating shading in post-planting, whose limitations become more significant for the plants and require adaptation to the new environment. This information is important because, with plasticity, species are more likely to survive in harsh conditions for their ability to adapt physiologically, biochemically and morphologically.

Evaluating plants in shading experiments addresses physiological parameters such as chlorophylls and carotenoids contents, which provides important information on the establishment, growth and plasticity of the pho- tosynthetic apparatus (Afonso et al. 2012). In addition to morphological parameters as height and stem diameter. These photosynthetic pigments are used in works as quality indicators for the seedlings. It is expected that shading may affect the growth of Apuleia leiocarpa seedlings in the field, presenting higher growth as the intensity of shading increases. Thus, to establish the suitable planting condition for Apuleia leiocarpa, the study aimed to identify the most appropriate level of shading for the initial growth of seedlings of species, through plant survival and morphological and physiological/biochemical parameters.

\section{METHODS}

Characterization of the study area. The experiment was conducted for a year (2012-2013) in an area near to the Forestry and Nursery Laboratory of the Department of Forest Sciences of the Federal University of Santa Maria (UFSM) ( $29^{\circ} 43^{\prime} 12.65^{\prime \prime}$ S; 53 $3^{\circ} 43^{\prime}$ 08.74" O), Rio Grande do Sul State (RS), Brazil. According to Köppen's classification, the local climate is ' $\mathrm{Cfa}$ ' (humid subtropical), with mean temperature in the coldest month between 3 and $18^{\circ} \mathrm{C}$, and in the warmest month above $22^{\circ} \mathrm{C}$; and mean annual precipitation of 1,600-1,900 mm (Alvares et al. 2013). Temperature (minimum, average and maximum) and monthly precipitation data are according to Alvares et al. (2013) during the study period and can be observed in figure 1 .

Seedlings of Apuleia leiocarpa were produced from October to July in the Forestry Laboratory in $110 \mathrm{~cm}^{3}$ containers. The commercial substrate peat based on Sphagnum, plus $20 \%$ of carbonized rice husk, was used. In the base fertilization Osmocote ${ }^{\circledR}$ (15-9-12), $6 \mathrm{~g} \mathrm{~L}^{-1}$ substrate was used. They were randomly selected for planting in the field and presented the following averages: $31.60( \pm 3.94)$ $\mathrm{cm}$ of height $(\mathrm{H}) ; 3.94( \pm 0.40) \mathrm{mm}$ of stem diameter $(\mathrm{SD})$ and $8.05( \pm 0.89) \mathrm{cm} \mathrm{mm}^{-1}$ of H/SD ratio.

Prior to planting, soil characterization of the area was performed in the Soil Analysis Laboratory (UFSM), which showed the following characteristics: low organic matter content (1.3 to $2.0 \%$ ), phosphorus level from very low to low (3.4 to $5.3 \mathrm{mg} \mathrm{dm}^{-3}$ ), high potassium level (60 to $82 \mathrm{mg}$ $\mathrm{dm}^{-3}$ ), high magnesium level ( 1.3 to $\left.2.5 \mathrm{cmol}_{\mathrm{c}} \mathrm{dm}^{-3}\right)$, calcium level from medium to high ( $\left.3.5 \mathrm{a} 7.4 \mathrm{cmol}_{\mathrm{c}} \mathrm{dm}^{-3}\right)$, average cation exchange capacity $\left(\mathrm{CEC}_{\mathrm{pH}} 7.0\right)$ (12.4 to 13.2 $\left.\mathrm{cmol}_{\mathrm{c}} \mathrm{dm}^{-3}\right)$, SMP index ranging from 5.4 to 6.4 and texture 3 (SBCS/CQFS 2004). Based on chemical properties, soil $\mathrm{pH}$ was adjusted to 5.5 with lime (PRNT $75.1 \%$ ) in the total area and it was incorporated into the soil one month before planting. Different intensities of shading were used as treatments: T1 $-0 \%$ (full sun - control), T2 - $18 \%$, T3 $-50 \%$ and $\mathrm{T} 4-70 \%$. The different shading intensities were obtained using nylon mesh on 2-meter-high arches in the center of the tunnel.

Planting spots were opened $(30 \mathrm{~cm}$ of diameter x 35 $\mathrm{cm}$ depth) and aligned in the east/west direction, spaced $1 \times 1 \mathrm{~m}$. Spots were filled with the same soil as described 


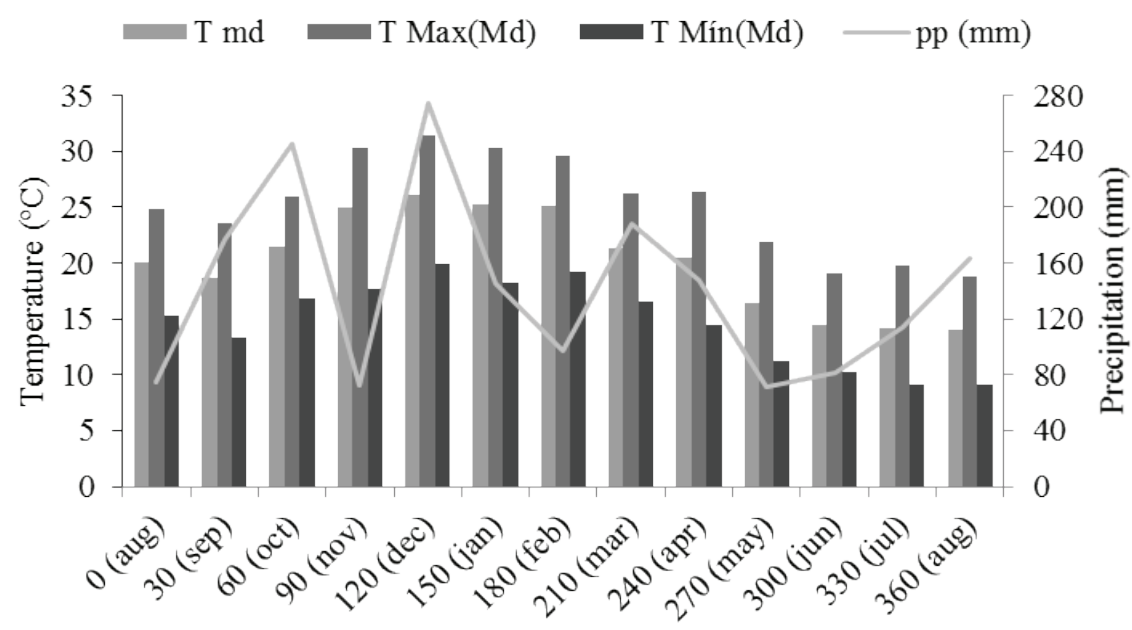

Days after planting (months)

Figure 1. Monthly climatic data of Santa Maria (RS) in "year" during the experiment with Apuleia leiocarpa seedlings. T= temperature $(\mathrm{md}=$ average; $\mathrm{Max}=$ maximum; Min $=$ minimum $) ; \mathrm{pp}=$ precipitation. Source: Climatological Station of Santa Maria, Federal University of Santa Maria.

Datos climatológicos de Santa Maria (RS) durante el experimento a campo con plantas Apuleia leiocarpa . $\mathrm{T}=$ temperatura $(\mathrm{md}=$ media; Max = máxima; Min = mínima); pp = precipitaciones. Fuente: Estación Climatológica Principal de Santa María, Universidad Federal de Santa María.

previously and added with $500 \mathrm{~mL}$ of commercial substrate containing barley residue, to improve both physical and chemical qualities of the soil. Substrate used showed these characteristics: $\mathrm{pH} 4.66,560.12 \mathrm{~kg} \mathrm{~m}^{-3}$ dry density, $81.05 \%$ total porosity, $5.83 \%$ aeration space, $23.39 \%$ easily available water and $18.72 \%$ buffering water

In absence of precipitation, seedlings were irrigated every two days in the first month, with two liters of water per plant and subsequently once a week. Dry vegetation cover (mulching) was placed around the seedlings with approximately $35 \mathrm{~cm}$ in diameter and $5 \mathrm{~cm}$ in height. Cover fertilizing was performed at 30 and 180 days after planting (d.a.p), with NPK (5-20-20). Two lateral holes were opened for each seedling for application of $100 \mathrm{~g}$ of fertilizer $(50 \mathrm{~g}$ in each side) at a distance of approximately $10 \mathrm{~cm}$ from the plant. Silvicultural treatments, such as insecticide application, ant control, crowning with manual weeding surrounding the seedlings and in line control of weed competition by herbicide application on two occasions (120 and 180 days after planting), were performed during the experiment.

Survival evaluation was performed at 30 and 360 d.a.p and morphological parameters such as height $(\mathrm{H})$ and stem diameter (SD) were measured at the time of planting and, afterward, bimonthly (60, 120, 180, 240, 300 and 360 d.a.p). Height was measured with a ruler $(\mathrm{cm})$ and stem diameter with a digital caliper $(\mathrm{mm})$ to provide the H/SD ratio. In addition, an analysis of the absolute growth rate (AGR) for $\mathrm{H}$ and $\mathrm{SD}$ was performed by using the following formula (Benincasa 2003):

$$
\operatorname{AGR}=\left(\mathrm{H}_{1}-\mathrm{H}_{0}\right) /\left(\mathrm{T}_{1}-\mathrm{T}_{2}\right)
$$

Where: $\mathrm{AGR}=$ Absolute growth $(\mathrm{AGR}) ; \mathrm{H}_{1}=$ Height at time $\mathrm{n} ; \mathrm{H}_{0}=$ Height at time $\mathrm{n}-1 ; \mathrm{T}_{1}=$ Number of days of time $n ; \mathrm{T}_{0}=$ Number of days of time $\mathrm{n}-1$.

Physiological characteristics such as chlorophyll content, carotenoids, lipid peroxidation and activity of acid phosphatase enzyme were analyzed in the Plant Biochemistry Laboratory of the Biology Department (UFSM) at 180 and 360 d.a.p. For these analyses, the fourth expanded leaf from the apical meristem of three plants was collected per treatment, which were immediately frozen in liquid nitrogen and stored at $-80{ }^{\circ} \mathrm{C}$ in an ultrafreezer until quantification. The contents of chlorophyll $a$, chlorophyll $b$ and carotenoids were determined by following the methodology described by Hiscox and Israeslstam (1979) and estimated using the formula of Lichtenthaler (1987). The fresh samples of leaves $(0.1 \mathrm{~g})$ were incubated at $65{ }^{\circ} \mathrm{C}$ with dimethylsulfoxide (DMSO) for two hours. Subsequently, the absorbance of the solution was measured in a spectrophotometer at 663,645 and $470 \mathrm{~nm}$. The peroxidation of membrane lipids was estimated according to the methodology of El-Moshaty et al. (1993) and expressed as nmol MDA mg ${ }^{-1}$ of protein. The activity of the acid phosphatase enzyme was determined according to the methodology of Tabaldi et al. (2007).

Determination of chlorophyll $a$ fluorescence was performed using a portable fluorometer (Junior-Pam ${ }^{\circledR}$ ) in fully expanded leaves from plants at 180 and 360 d.a.p. The selected leaves were submitted to 30 minutes in the dark. After that, they were exposed to saturated light pulses at an induced wavelength by red light (peak at $650 \mathrm{~nm}$ ) 
for approximately $3.000 \mu \mathrm{mol} \mathrm{m} \mathrm{m}^{-2} \mathrm{~s}^{-1}$, obtaining the initial fluorescence signs (Fo), maximum fluorescence (Fm), maximum quantum yield of the photosystem II ( $\mathrm{Fv} / \mathrm{Fm})$ and electron transport rate (ETR).

Design and statistical analysis. Experimental design was set up as randomized blocks, with four treatments (shading levels) in five blocks totaling 80 seedlings. The statistical analysis was carried out using SISVAR software 5.3 (Ferreira 2011), submitting the data to normality and homogeneity and subsequently to the ANOVA analysis. Means were compared by Tukey test at $5 \%$ probability.

\section{RESULTS}

At 30 days after planting (d.a.p), there was no mortality of Apuleia leiocarpa seedlings. Survival rate was high and without influence of different levels of shading. However, high mortality rates were observed at 360 d.a.p., especially in full sun (table 1).

Table 1. Survival rate of Apuleia leiocarpa seedlings at 30 and 360 days after planting in the field, at different levels of shading.

Tasa de supervivencia de plantas de Apuleia leiocarpa a los 30 y 360 días después del trasplante a campo, en diferentes niveles de sombra.

\begin{tabular}{ccc}
\hline \multirow{2}{*}{ Level of shading (\%) } & \multicolumn{2}{c}{ Survival (\%) } \\
\cline { 2 - 3 } & 30 d.a.p & 360 d.a.p \\
\hline 0 & $100 \mathrm{a}^{*}$ & $50 \mathrm{~b}$ \\
18 & $100 \mathrm{a}$ & $90 \mathrm{a}$ \\
50 & $100 \mathrm{a}$ & $80 \mathrm{ab}$ \\
70 & $100 \mathrm{a}$ & $95 \mathrm{a}$ \\
\hline
\end{tabular}

* Averages followed by different letters in the column differ from each other by the Tukey test $(P<0.05)$.
Absolute growth rate (AGR) in height and stem diameter shows the same behavior, which is observed zero or reduced growth at 60 days. However, after the establishment during the spring, there was significant growth in subsequent seasons in up to 240 days, which coincides with the fall (figure 1), followed by the decrease in the dormant period (figures 2 and 3).

In the assessments performed at 180 and 360 d.a.p., there was no significant difference among levels of shading for $\mathrm{H}$ and SD (table 2). The H/SD showed lower seedling stability under 50 and $70 \%$ of shading, especially at 180 days, when there was a reduction of photoperiod and temperature (figure 1).

Shading levels and age of the plants (180 and 360 days) significantly influenced $(P<0.05)$ the content of photosynthetic pigments (table 3). Chlorophyll contents were higher at the highest shading condition, especially at 360 d.a.p (winter) under $70 \%$. Moreover, it is important to emphasize that Chl $a$ was always higher in the winter, while Chl $b$ showed the highest oscillation (table 3). $C h l a / b$ ratio shows more variation in data when comparing both shading and different season growths (winter and summer). At 360 d.a.p, a higher content of 18 and $50 \%$ levels was observed.

Carotenoid content was higher in plants with $50 \%$ of shading at 180 days and with $70 \%$ at 360 days (table 3 ). Similarly, Chl a content values were the highest at 360 days under any level of shading.

There was no significant difference among treatments for lipid peroxidation content at 180 days, although, at 360 days that value was higher in absence of protective mesh (full sun) (table 4). For acid phosphatase enzyme, there was no difference among treatments at 180 days, while at 360 days that activity was higher with 0 and $50 \%$ of shading. The acid phosphatase enzyme was enhanced at 180 days, although there was no difference among treatments. On the other hand, at 360 days, full sun and $50 \%$ of shading were higher.

Table 2. Height $(\mathrm{cm})$, stem diameter $(\mathrm{mm})$ and ratio H/SD averages of Apuleia leiocarpa seedlings in full sun $(0 \%)$ and different intensities of shading $(18,50$ and $70 \%)$, at 180 and 360 days.

Medias de altura $(\mathrm{cm})$, diámetro del cuello $(\mathrm{mm})$ y relación H/DC de plantas de Apuleia leiocarpa, a pleno sol $(0 \%)$ y diferentes niveles de sombra $(18,50$ y $70 \%)$ a 180 y 360 días.

\begin{tabular}{ccccccc}
\hline \multirow{2}{*}{$\begin{array}{c}\text { Level of shading } \\
(\%)\end{array}$} & $\begin{array}{c}\text { Height } \\
(\mathrm{H})\end{array}$ & $\begin{array}{c}\text { Stem diameter } \\
(\mathrm{SD})\end{array}$ & $\begin{array}{c}\mathrm{H} / \mathrm{SD} \\
\text { ratio }\end{array}$ & $\begin{array}{c}\text { Height } \\
(\mathrm{H})\end{array}$ & $\begin{array}{c}\text { Stem diameter } \\
(\mathrm{SD})\end{array}$ & $\begin{array}{c}\text { H/SD } \\
\text { Ratio }\end{array}$ \\
\cline { 2 - 7 } & & 180 days & & $79.65 \mathrm{a}$ & $11.50 \mathrm{a}$ & $6.53 \mathrm{a}$ \\
\hline 0 & $46.04 \mathrm{a}^{*}$ & $7.41 \mathrm{a}$ & $6.25 \mathrm{ab}$ & $82.18 \mathrm{a}$ & $12.36 \mathrm{a}$ & $6.68 \mathrm{ab}$ \\
18 & $47.60 \mathrm{a}$ & $7.92 \mathrm{a}$ & $6.01 \mathrm{a}$ & $92.33 \mathrm{a}$ & $10.19 \mathrm{a}$ & $9.04 \mathrm{c}$ \\
50 & $51.02 \mathrm{a}$ & $7.25 \mathrm{a}$ & $6.97 \mathrm{ab}$ & $92.63 \mathrm{a}$ & $10.41 \mathrm{a}$ & $8.79 \mathrm{bc}$ \\
70 & $59.19 \mathrm{a}$ & $7.23 \mathrm{a}$ & $8.33 \mathrm{~b}$ & 91.95 & 33.07 & 14.75 \\
\hline $\mathrm{CV}(\%)$ & 33.46 & 29.02 & 18.23 & 45 & \\
\hline
\end{tabular}

* Averages followed by different letters in the column differ from each other by the Tukey test $(P<0.05)$. CV: Coefficient of variation. 
There was no significant interaction between shading $\mathrm{x}$ time for chlorophyll $a$ fluorescence variables. Initial fluorescence (Fo), maximum fluorescence (Fm), Fv/Fm ratio and ETR showed significance for isolated factors $(P<0.05)$. Fo values increased at higher levels of shading
(50 and $70 \%$ ), similarly to Fm. During winter (360 days) Fo was significantly higher in the summer (360 days), which was similar to Fm, however, in this case there was no statistical difference $(P=0.2980)$ (table 5).

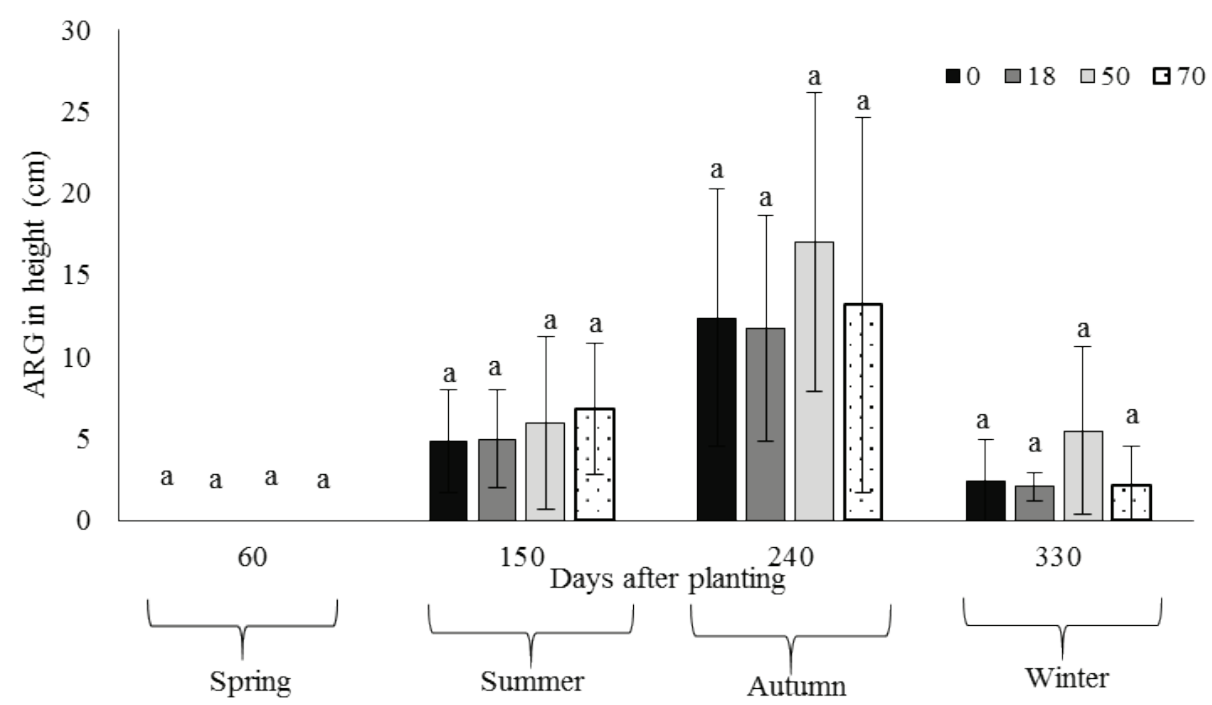

Figure 2. Absolute growth rate (AGR) in height of Apuleia leiocarpa seedlings in different levels of shading $(0,18,50$ and $70 \%)$, as a function of days after planting. Averages followed by different letters in each season differ from each other by the Tukey test $(P<0.05)$.

Tasa de crecimiento absoluto (TCA) en altura de plantas Apuleia leiocarpa en diferentes intensidades de sombra (0, 18 , 50 y $70 \%$ ), en función de los días después del trasplante. Medias seguidas por letras diferentes en cada estación, se diferencian por la prueba de Tukey $(P<0,05)$.

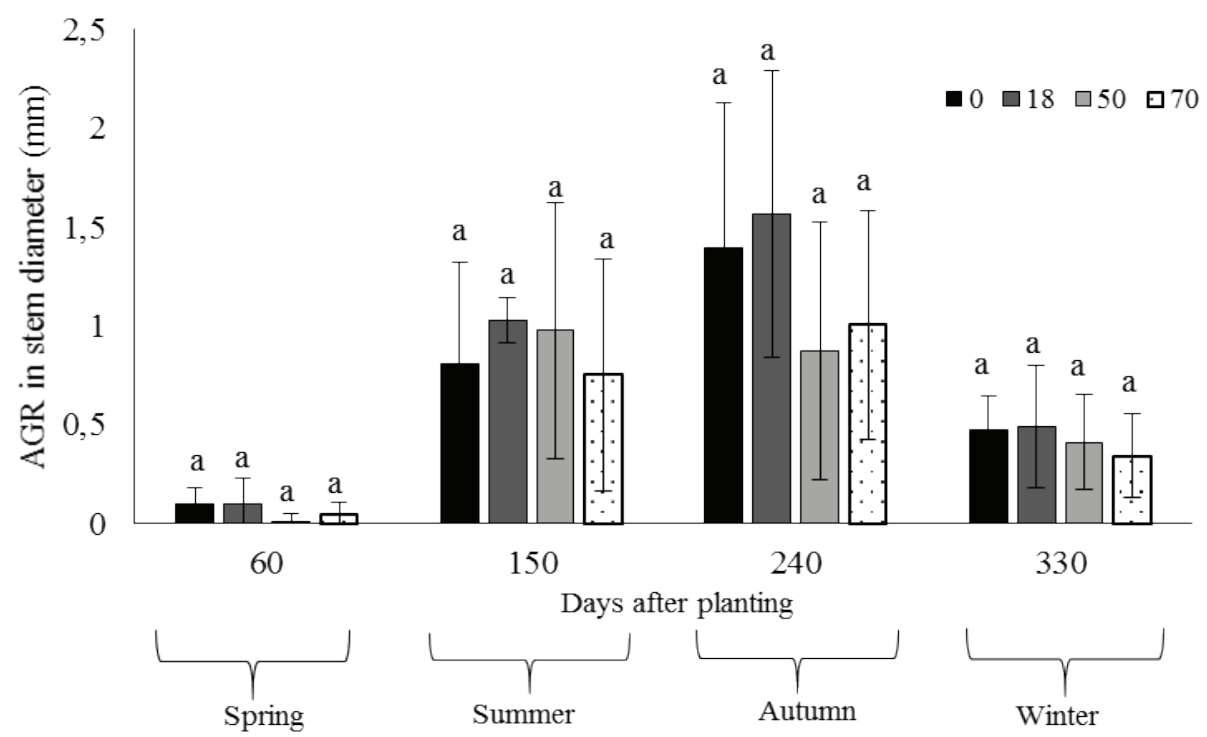

Figure 3. Absolute growth rate (AGR) in stem diameter of Apuleia leiocarpa seedlings in different levels of shading $(0,18,50$ and $70 \%)$, as a function of days after planting. Averages followed by different letters in each season differ from each other by the Tukey test $(P<0.05)$.

Tasa de crecimiento absoluto (TCA) del diámetro del cuello de plantas de Apuleia leiocarpa en diferentes intensidades de sombra $(0,18$, 50 y $70 \%$ ), en función de los días después del trasplante. Medias seguidas por letras diferentes en cada estación, se diferencian entre sí por la prueba de Tukey $(P<0,05)$. 
Table 3. Averages of chlorophyll $a, b$ and Chl $a / b$ ratio of Apuleia leiocarpa seedlings in full sun (0\%) and in different levels of shading $(18,50$ and $70 \%)$, at 180 and 360 days after planting.

Medias de clorofila $a$, clorofila $b$, y relación $C h l a / b$ de plantas de Apuleia leiocarpa en pleno sol (0\%) y diferentes intensidades de sombra $(18,50$ y $70 \%)$ después de 180 y 360 días en campo.

\begin{tabular}{|c|c|c|c|c|c|c|c|c|}
\hline \multirow{3}{*}{$\begin{array}{c}\text { Level of } \\
\text { shading } \\
(\%)\end{array}$} & \multicolumn{2}{|c|}{ Chlorophyll $a\left(\mathrm{mg} \mathrm{g}^{-1} \mathrm{FM}\right)$} & \multicolumn{2}{|c|}{ Chlorophyll $b$ (mg g $\left.{ }^{-1} \mathrm{FM}\right)$} & \multicolumn{2}{|c|}{$C h l a / b$ ratio } & \multicolumn{2}{|c|}{ Carotenoids (mg g $\left.\mathrm{g}^{-1} \mathrm{FM}\right)$} \\
\hline & \multicolumn{8}{|c|}{ Days after planting } \\
\hline & 180 & 360 & 180 & 360 & 180 & 360 & 180 & 360 \\
\hline 0 & $0.82 \mathrm{Bc}^{*}$ & $1.26 \mathrm{Ab}$ & $0.15 \mathrm{Bc}$ & $0.27 \mathrm{Ab}$ & $5.57 \mathrm{Aa}$ & $4.65 \mathrm{Ba}$ & $0.28 \mathrm{Bb}$ & $0.45 \mathrm{Ab}$ \\
\hline 18 & $1.00 \mathrm{Bb}$ & $1.15 \mathrm{Ab}$ & $0.24 \mathrm{Ab}$ & $0.24 \mathrm{Ab}$ & 4.24 Acb & $4.72 \mathrm{Aa}$ & $0.17 \mathrm{Bd}$ & $0.40 \mathrm{Ac}$ \\
\hline 50 & $1.10 \mathrm{Bb}$ & $1.28 \mathrm{Ab}$ & $0.33 \mathrm{Aa}$ & $0.26 \mathrm{Bb}$ & $3.33 \mathrm{Bc}$ & $4.86 \mathrm{Aa}$ & $0.32 \mathrm{Ba}$ & $0.42 \mathrm{Ac}$ \\
\hline 70 & $1.32 \mathrm{Ba}$ & $1.84 \mathrm{Aa}$ & $0.29 \mathrm{Bab}$ & $0.69 \mathrm{Aa}$ & 4.63 Aab & $2.68 \mathrm{Bb}$ & $0.25 \mathrm{Bc}$ & $0.55 \mathrm{Aa}$ \\
\hline $\mathrm{CV}(\%)$ & \multicolumn{2}{|c|}{5.45} & \multicolumn{2}{|c|}{7.78} & \multicolumn{2}{|c|}{12.19} & \multicolumn{2}{|c|}{3.74} \\
\hline
\end{tabular}

*Averages followed by different capital letters on the line and lower in the column differ from each other by the $\mathrm{t}$ (line) and Tukey (column) tests $(P<0.05)$; CV: Coefficient of variation and FM = fresh mass.

Table 4. Averages of lipid peroxidation and acid phosphatase enzyme of Apuleia leiocarpa seedlings in full sun ( $0 \%)$ and in different levels of shading (18,50 and $70 \%)$, at 180 and 360 days after planting.

Medias de peroxidación lipídica y actividad de la enzima fosfatasa ácida de plantas de Apuleia leiocarpa en pleno sol (0 \%) y diferentes intensidades de sombra (18, 50 y $70 \%$ ), a los 180 y 360 días en campo.

\begin{tabular}{|c|c|c|c|c|}
\hline \multirow{3}{*}{$\begin{array}{l}\text { Level of shading } \\
\qquad(\%)\end{array}$} & \multicolumn{2}{|c|}{ Lipid peroxidation (mmol de $\left.\mathrm{MDA}^{-1} \mathrm{FM}\right)$} & \multicolumn{2}{|c|}{ Acid phosphatase enzyme (nmol Pi $\mathrm{g} \mathrm{FW}^{-1} \mathrm{~min}^{-1}$ ) } \\
\hline & \multicolumn{4}{|c|}{ Days after planting } \\
\hline & 180 & 360 & 180 & 360 \\
\hline 0 & $0.77 \mathrm{Aa}$ & $1.23 \mathrm{Bc}$ & $5.97 \mathrm{Aa}$ & $8.90 \mathrm{Ba}$ \\
\hline 18 & $0.59 \mathrm{Aa}$ & $0.77 \mathrm{Aab}$ & $5.93 \mathrm{Aa}$ & $9.47 \mathrm{Bb}$ \\
\hline 50 & $0.48 \mathrm{Aa}$ & $0.44 \mathrm{Aa}$ & $5.96 \mathrm{Aa}$ & $8.59 \mathrm{Ba}$ \\
\hline 70 & $0.49 \mathrm{Aa}$ & $0.89 \mathrm{Bb}$ & $5.88 \mathrm{Aa}$ & $9.52 \mathrm{Bb}$ \\
\hline $\mathrm{CV}(\%)$ & \multicolumn{2}{|c|}{20.27} & \multicolumn{2}{|c|}{1.87} \\
\hline
\end{tabular}

*Averages followed by different capital letters on the line and lower in the column differ from each other by the $\mathrm{t}$ (line) and Tukey (column) tests $(P<0.05)$; CV: Coefficient of variation and $\mathrm{FM}=$ fresh mass.

Table 5. Chlorophyll $a$ initial fluorescence (Fo), maximum fluorescence (Fm), maximum quantum yield of photosystem II (Fv/Fm) and electron transport rate (ETR) in Apuleia leiocarpa seedlings in different levels of shading (0, 18, 50 and $70 \%)$, at 180 and 360 days after planting.

Fluorescencia inicial de la clorofila $a(\mathrm{Fo})$, fluorescencia máxima (Fm), rendimiento cuántico máximo del fotosistema II (Fv/Fm) y tasa de transporte de electrones (ETR) en plantas de Apuleia leiocarpa en diferentes intensidades de sombra (0, 18, 50 y $70 \%$ ), a los 180 y 360 días en campo.

\begin{tabular}{ccccc}
\hline Level of shading $(\%)$ & Fo & Fm & Fv/Fm & ETR \\
\hline 0 & $206.83 \mathrm{~b}^{*}$ & $393.92 \mathrm{~b}$ & $0.53 \mathrm{a}$ & $22.37 \mathrm{a}$ \\
18 & $252.50 \mathrm{~b}$ & $527.00 \mathrm{~b}$ & $0.52 \mathrm{a}$ & $0.62 \mathrm{a}$ \\
50 & $306.33 \mathrm{ab}$ & $794.17 \mathrm{a}$ & $0.52 \mathrm{a}$ & $17.29 \mathrm{a}$ \\
70 & $457.33 \mathrm{a}$ & $879.33 \mathrm{a}$ & Fv/Fm & $15.71 \mathrm{a}$ \\
\hline Time & Fo & Fm & $0.6267 \mathrm{a}$ & $21.82 \mathrm{a}$ \\
\hline 180 & $227.92 \mathrm{~b}$ & $617.04 \mathrm{a}$ & $0.4675 \mathrm{~b}$ & $15.70 \mathrm{~b}$ \\
\hline CV $(\%)$ & $383.58 \mathrm{a}$ & $680.17 \mathrm{a}$ & 21.74 & 31.94 \\
\hline
\end{tabular}

*Averages followed by different letters in the column differ from each other by the Tukey test (levels of shading) and the $\mathrm{t}$ test (time) $(P<0.05) \mathrm{e} \mathrm{CV}$ : Coefficient of variation. 
The Fv/Fm ratio was not significant among shading levels, corresponding to $55 \%$ of photons arriving in the plant and being transferred to the photochemical route. The largest luminous energy transfer occurred in the summer (table 5). These results correspond to the electron transport rate as observed, regarding both, level of shading and evaluation season.

\section{DISCUSSION}

The present study shows the effect of shading during the initial establishment of Apuleia leiocarpa seedlings in the field, required to achieve higher survival rates and to increase the physiological performance of the plants (tables 3, 4 and 5). In this study, the effect of shading levels on survival, growth and physiological characteristics of Apuleia leiocarpa seedlings in the initial field establishment is reported for the first time.

Among the environmental factors, solar radiation has an important role in photosynthesis, regulating the survival, growth and adaptation of plants (Zervoudakis et al. 2012). The survival of Apuleia leiocarpa seedlings in 360 days was positively influenced by increased levels of shading. High mortality of Apuleia leiocarpa in full sun could be associated with the fact that the species requires more protection in the early stage of development, which possibly is related to the reduced shading and the influence of lower temperatures. This result could be associated with the level of lipid peroxidation, which was higher in full sun at 360 days, and with the content of carotenoids, which were lower in less shaded treatments at 360 days. Probably, carotenoids did not protect Apuleia leiocarpa plants from the excess of light and, consequently, there was higher lipid peroxidation and plant mortality. Some of these results corroborates Carvalho (2003), who classifies Apuleia leiocarpa as a species with semi-heliophile behavior. Under natural conditions, in the regeneration phase, this species has a tolerance to low light intensities, due to closed canopy.

Apuleia leiocarpa plants showed similar behavior for TCR in height and stem diameter. Variation of AGR is an expected response, since any increase over a certain period is directly related to the dimensions previously reached (Lima et al. 2007).

The species behavior in relation to the irradiance is distinguished, mainly when seedlings come to growth in the field, indicating different tolerance levels demanded, which is important for plant development and use in forestry. Aimi (2014) and Tonetto (2014), studying respectively Cabralea canjerana Vell. Mart. (canjerana) and Handroanthus heptaphyllus (Mart.) Mattos (ipê-roxo), observed antagonistic behavior of species in relation to light requirement, with the highest growth occurring under 50 $\%$ of shading and full sun, respectively.

In addition to the high survival of Apuleia leiocarpa seedlings under $18 \%$ of shading, we also found a higher carbon allocation in stem diameter in relation to height, a fact opposed to the condition of $50 \%$ of shading. The acid phosphatase enzyme was more active at 360 days under $70 \%$ shading, indicating that the phosphorus mobilization promoted by this enzyme may have contributed to increasing stem diameter. Several studies have shown that height/stem diameter ratio of trees decreases with light availability, suggesting that shading affects the growth in diameter more negatively than does height growth (Petri$\tan$ et al. 2009).

Almeida et al. (2004) reported that plant growth might reflect the ability of species adaptation to environmental radiation conditions in which they are developing. Furthermore, Scalon et al. (2002) reported that growth characteristics are used to infer the degree of species tolerance to low light availability.

The increase of photosynthetic pigment content in leaves of plants due to the increase in shading is a response widely described in literature (Lichtenthaler et al. 2007). In this study, increasing the level of shading for Apuleia leiocarpa plants caused an increase in photosynthetic pigment content. At 180 days (summer), an increase of chlorophyll $a$ and $b$ was observed in higher shading levels in order to meet the minor incident radiation, as well as at 360 days.

It is noteworthy that, possibly, the species needs to invest in the production of pigments to better capture incident light energy. This response allows the plant to maximize the gain in carbon and changes in light interception. Chlorophyll is constantly being synthesized and destroyed (photooxidation) in the presence of light, nevertheless, under higher light intensities further degradation occurs and balance is established at a lower concentration (Almeida et al. 2004). This is confirmed by the increase of carotenoids, which absorb different wavelengths, from those absorbed by Chl $a$ and $b$. There was an increase in chlorophyll production and $70 \%$ shading at 360 days. Typically, carotenoids acquire the ability to increase with decreasing light intensity and may perform different functions during photosynthesis, such as absorption in the light-harvesting complex and photoprotection of the photochemical apparatus (Kerbauy 2004).

The behavior of Apuleia leiocarpa in the south region of Brazil demonstrated to be similar to which was found in other studies, such as Rêgo and Possamai (2006); when evaluating light (full sun, 34, 44, 64 and $70 \%$ ) in Cariniana legalis Cariniana legalis Kuntze (jequitibá-rosa), they observed that the contents of chlorophyll $a, b$ and total were higher in plants under lower light condition. Lima et al. (2010) confirmed that the highest carotenoid content in Hymenaea courbaril L. (jatoba) and Enterolobium contortisiliquum (Vell.) Morong. (timbaúva) occurred under shading, thus differing from those in full sun.

In the present study, it was found that the chlorophyll $a / b$ ratio showed high values under full sun (5.5 and 4.6, respectively at 180 and 360 d.a.p) with reduction due to 
shading increase (2.6; $70 \%$ shading to 360 d.a.p). In general, chlorophyll $a / b$ ratio increases with higher irradiance in plants, however this feature could respond differently given the availability of nitrogen (Maina and Wang 2015). Under shading conditions, plants show less chlorophyll $a / b$ compared to plants in full sun due to the high portion of chlorophyll $b$ assigned to the antenna complex. Streit et al. (2005) describe this relationship in plants occurs at 3:1 ratio.

According to Taiz and Zeiger (2013), some plants have plasticity to adapt to a range of light regimes and can grow in full sun or in shady environments. The Fv/Fm ratio has been the most commonly used parameter for characterizing conditions affecting the photochemical efficiency of plants under stress conditions (Lichtenthaler et al. 2007, Bussotti and Pollastrini 2015). In general, low values of $\mathrm{Fv} / \mathrm{Fm}$ ratio indicate foliar photoinhibition (Cascio et al. 2010). According to our results, there was a significant difference between the values of Fv/Fm estimated in leaves of Apuleia leiocarpa in different seasons. Plants subjected to stress caused by low winter temperatures had lower values of Fv/Fm (0.47) compared to the value observed at higher temperatures (0.63).

Even there was higher initial and maximum fluorescence in the treatments with 50 and $70 \%$ of shading, no significant difference was found among treatments for maximum quantum yield of photosystem II (Fv/Fm) and electron transport rate (ETR). That indicates the biomass production was not affected in high shading treatments, since there was no significant difference between treatments for height and stem diameter of Apuleia leiocarpa under $18 \%$ and $50 \%$ of shading, they showed values of Fv/Fm closed to 0.55 and electron transport rate around $18 \mu \mathrm{mol}$ electrons $\mathrm{m}^{-2} \mathrm{~s}^{-1}$. Ritchie et al. (2010) described that Fv/Fm below 0.6 and electron transport rate higher than $300 \mu \mathrm{mol}$ electrons $\mathrm{m}^{-2} \mathrm{~s}^{-1}$ represent stress to plants. However, there is wide variation between species, and we believe that in these environments (18\% and $50 \%$ of shading) in which there was high survival rate, such values were not limited to the establishment of the species and could be considered appropriate to be a reference on the photochemical efficiency of Apuleia leiocarpa.

The significant reduction of photochemical efficiency $(\mathrm{Fv} / \mathrm{Fm})$ of the plants of Apuleia leiocarpa between 180 and 360 days after planting was probably due to the inhibitory effect of photosynthesis because of the average temperature difference among times. Probably, at 360 days, higher temperatures were observed, which might have reduced Fv/Fm values. This pattern of reducing the photochemical efficiency due to injuries caused by low temperature has already been observed in Pinus sylvestris L. (Linkosalo et al. 2014).

Adaptation to light intensities is a genetic characteristic, since leaves have anatomical structure and physiological properties able to, effectively, use the available solar radiation. In this sense, considering that Apuleia leiocar- pa has wide distribution, it could be planted in different latitudes, light intensities and temperatures, except in the condition of full sun and high shading.

\section{CONCLUSIONS}

The initial hypothesis of this study is confirmed: shading affects the growth of seedlings Apuleia leiocarpa in the field.

Morphological and physiological parameters of Apuleia leiocarpa plants evidence that this species requires shading (18 to $50 \%$ ) in its early stage of development in the field.

\section{ACKNOWLEDGEMENTS}

To the Higher Education Personnel Improvement Coordination (Coordenação de Aperfeiçoamento de Pessoal de Nível Superior, CAPES) for granting scholarships to the first and third authors and to the National Scientific and Technological Development Council (Conselho Nacional de Desenvolvimento Científico e Tecnológico, CNPq) for the scholarship of productivity in research provided to the second author.

\section{REFERENCES}

Afonso MV, EG Martinazzo, TZ Aumonde, FA Villela. 2012. Composição do substrato, vigor e parâmetros fisiológicos de mudas de timbaúva (Enterolobium contortisiliquum (Vell.) Morong). Revista Árvore 36(6): 1019-1026.

Aimi SC. 2014. Tecnologia de sementes e crescimento inicial de mudas de Cabralea canjerana (Vell.) Mart. Master Thesis (Mestrado em Engenharia Florestal). Santa Maria, Brasil. Universidade Federal de Santa Maria. 110 p.

Almeida LP, AA Alvarenga, EM Castro, SM Zanela, CV Vieira. 2004. Crescimento inicial de plantas de Cryptocaria aschersoniana Mez. submetidas a níveis de radiação solar. Revista Ciência Rural 34(1): 83-88.

Alvares CA, JL Stape, PC Sentelhas, JLM Gonçalves, G Sparovek. 2013. Köppen's climate classification map for Brazil. Meteorologische Zeitschrift 22(6): 711-728.

Azevedo GT de OS, AB de Novaes, GB de Azevedo, HF Silva. 2015. Desenvolvimento de mudas de nim indiano sob diferentes níveis de sombreamento. Floresta Ambiente 22(2): 249-255.

Backes P, B Irgang. 2009. Árvores do sul: guia de identificação e interesse ecológico. Porto Alegre, Brasil. Paisagem do Sul. $332 \mathrm{p}$.

Benincasa MMP. 2003. Crescimento absoluto-apresentação dos dados. In Benincasa MMP. Análise de crescimento de plantas (noções básicas). Jaboticabal, Brasil. FUNEP. p. 20-24.

Bogaert J, YSS Barima, WML Iyongo, I Bamba, A Mama, M Toyi. 2011. Forest fragmentation: causes, ecological impacts and implications for landscape management. In $\mathrm{Li}$ C, R Lafortezza, J Chen eds. Landscape Ecology in Forest Management and Conservation: Challenges and Solutions for Global Change. Beijing, China. Higher Education 
Press-Springer. p. 273-296.

Brancalion PHS, RAG Viani, RR Rodrigues, S Gandolfi. 2012. Avaliação e Monitoramento de Áreas em Processo de Restauração. In Martins SV. (Org.). Restauração ecológica de ecossistemas degradados. Viçosa, Minas Gerais. FV. p. 262-293.

Bussotti F, M Pollastrini. 2015. Do tree-species richness, stand structure and ecological factors affect the photosynthetic efficiency in European forests? Web Ecology 15(1): 39-41.

Carvalho PER. 2003. Espécies Arbóreas Brasileiras. Brasília: EMBRAPA Informação Tecnológica. Colombo, Brasil. EMBRAPA Florestas. 1039 p.

Carvalho AS, MV Silva, FS Gomes, PMG Paiva, CB Malafaia, TD Silva, AFM Vaz, AG Silva, IRS Arruda, TH Napoleão, MG Carneiro-da-Cunha, MTS Correia. 2015. Purification, characterization and antibacterial potential of a lectin isolated from Apuleia leiocarpa seeds. International Journal of Biological Macromolecules 75: 402-408.

Cascio C, M Schaub, K Novak, R Desotgiu, F Bussotti, RJ Strasser. 2010. Foliar responses to ozone of Fagus sylvatica L. seedlings grown in shaded and in full sunlight conditions. Environmental and Experimental Botany 68(2): 188-197.

El-Moshaty FIB, SM Pike, AJ Novacky, OP Sehgal. 1993. Lipid peroxidation and superoxide production in cowpea (Vigna unguiculata) leaves infected with tobacco ringspot virus or southern bean mosaic virus. Physiological and Molecular Plant Pathology 43(2): 109-119.

Ferreira DF. 2011. Sisvar: a computer statistical analysis system. Ciência e Agrotecnologia 35(6): 1039-1042.

Hiscox JD, GF Israelstam. 1979. A method for the extraction of chlorophyll from leaf tissue without maceration. Canadian Journal of Botany. 57(12): 1132-1334.

Kerbauy GB. 2004. Fisiologia Vegetal. Rio de Janeiro, Brasil. Guanabara Koogan. 452 p.

Kageyama PY, C Castro. 1989. Sucessão secundária, estrutura genética e plantações de espécies nativas. IPEF, Piracicaba 41(42): 83-93.

Lamprecht H. 1990. Silvicultura nos trópicos: ecossistemas florestais e respectivas espécies arbóreas - possibilidades e métodos de aproveitamento sustentado. Eschborn: Instituto de Silvicultura da Universidade de Göttingen. Göttingen, Germany. GTZ. 343 p.

Lichtenthaler HK. 1987. Chlorophylls and carotenoids: pigments of photosynthetic biomembranes. Methods in Enzymology 148: 350-382.

Lichtenthaler HK, AC Alexander, V Michal, MV Marek, J Kalina, O Urban. 2007. Differences in pigment composition, photosynthetic rates and chlorophyll fluorescence images of sun and shade leaves of four tree species. Plant Physiology and Biochemistry 45(8): 577-588.

Lima JL, CP Peixoto, CAS Ledo. 2007. Índices fisiológicos e crescimento inicial de mamoeiro (Carica papaya L.) em casa de vegetação. Ciência Agrotécnica 31(5): 1358-1363.

Lima ALS, F Zanella, LDM Castro. 2010. Crescimento de Hymenaea courbaril L. var. stilbocarpa (Hayne) Lee et Lang. e Enterolobium contortisiliquum (Vell.) Morong (Legumi- nosae) sob diferentes níveis de sombreamento. Acta Amazonica 40(1): 43-48.

Linkosalo T, J Heikkinen, P Pulkkinen, R Mäkipää. 2014. Fluorescence measurements show stronger cold inhibition of photosynthetic light reactions in Scots pine compared to Norway spruce as well as during spring compared to autumn. Frontiers in Plant Science 5: 1-8.

Maina JN, Q Wang. 2015. Seasonal Response of Chlorophyll a/b Ratio to Stress in a Typical Desert Species: Haloxylon ammodendron. Arid Land Research and Management 29(3): 321-334.

Petritan AM, B von Lupke, IC Petritan. 2009. Influence of light availability on growth, leaf morphology and plant architecture of beech (Fagus sylvatica L.), maple (Acer pseudoplatanus L.) and ash (Fraxinus excelsior L.) saplings. European Journal of Forest Research 128(1): 61-74.

Rêgo GM, E Possamai. 2006. Efeito do sombreamento sobre o teor de clorofila e crescimento inicial do jequitibá-rosa. Boletim de Pesquisa Florestal, Colombo 53: 179-194.

Ritchie GA, TD Landis, RK Dumroese. 2010. Assessing plant quality. Seedling Processing, Storage, and Outplanting. Vol 7, Agriculture Handbook 674. Washington DC, USA. U.S. Department of Agriculture Forest Service. 200 p.

SBCS/CQFS (Sociedade Brasileira de Ciência do Solo, BR / Comissão de Química e Fertilidade do Solo, BR). 2004. Manual de adubação e de calagem para os estados do RS e SC. 10 ed. Porto Alegre: Sociedade Brasileira de Ciência do Solo - Núcleo Regional Sul. 394 p.

SEMA (Secretaria Estadual do Meio Ambiente, BR). 2014. Homologada a nova lista de espécies ameaçadas de extinção. 08/12/2014. Anexo 1. Consulted 03 Apr. 2017. Available in $<$ http://www.fzb.rs.gov.br/conteudo/4809/?Homologada_a nova_Lista_da_Flora_Ga\% C3\% B Acha Amea\%C3\%A7ada_de_Extin $\% \mathrm{C} 3 \% \mathrm{~A} 7 \% \mathrm{C} 3 \% \mathrm{~A} 3 \mathrm{o}>$.

Scalon S de PQ, RM Mussury, MR Rigoni, F Veraldo. 2002. Crescimento inicial de mudas de espécies florestais nativas sob diferentes níveis de sombreamento. Revista Árvore 26(1): 1-5.

Streit NM, LP Canterle, MW Canto, LHH Hecktheuer. 2005. As clorofilas. Ciência Rural 35(3): 748-755.

Tabaldi LA, R Ruppenthal, D Cargnelutti, VM Morsch, LB Pereira, MRC Schetinger. 2007. Effects of metal elements on acid phosphatase activity in cucumber (Cucumis sativus L.) seedlings. Environmental and Experimental Botany 59(1): 43-48.

Taiz L, E Zeiger. 2013. Fisiologia Vegetal 3 ed. Porto Alegre, Brasil. Artmed. 720 p.

Tonetto TS da. 2014. Tecnologia de sementes e desenvolvimento de mudas de Handroanthus heptaphyllus (Mart.) Mattos sob diferentes formas de manejo no viveiro e no campo. Master Thesis (Mestrado em Engenharia Florestal). Santa Maria, Brasil. Universidade Federal de Santa Maria. 137 p.

Zervoudakis G, G Salahas, G Kaspiris, E Konstantopoulou. 2012. Influence of Light Intensity on Growth and Physiological Characteristics of Common Sage (Salvia officinalis L.). Brazilian Archives of Biology and Technology 55(1): 89-95. 
